\title{
Alustat paikallisen hallinnan välineenä - käsitteellinen tarkastelu
}

\author{
Kaisu Sahamies, Arto Haveri ja Ari-Veikko Anttiroiko
}

\begin{abstract}
The aim of this article is to shed light on the relevance of platforms in urban governance. Discussion starts with a brief description of the evolution of platform discourse and a critical view of how platforms relate to governance paradigms. As the idea of platform is often associated with openness and participation, this particular dimension is elaborated as a potentially beneficial feature of platform governance. In order to concretize the picture of platforms in the given context, this article presents a typology of urban platforms based on the most common platform functions. Our discussion reveals that while platforms have a connection with classic modes of governance, they have irreducible features worth acknowledging in the theorization of public governance. The type of platform, the level of analysis and social structures are preconditions for understanding the platform logic in urban governance.
\end{abstract}

Keywords: platform, platform governance, local governance, City as a Platform

\section{JOHDANTO}

Kaupungin hallinnon tehtävä ei ole pelkästään tarjota tiettyjä palveluja, vaan myös ohjata paikallisyhteisöä hyödyntämään omaehtoisesti kehittämismahdollisuuksiaan (Stoker 2011). Jotta kaupunki voisi onnistua tässä tehtävässä, sen on toimittava yhteistyössä julkisten ja yksityisten organisaatioiden ja kansalaisyhteiskunnan toimijoiden kanssa. Tällaisessa paikallisessa hallinnassa, joka edustaa ns. uuden julkisen hallinnan paradigmaa, on kysymys muiden kuin hierarkkisessa alaissuhteessa olevien toimijoiden ohjaamisesta, heidän toimintaansa vaikuttamisesta ja yhteistyön koordinoimisesta (ks. esim. Rhodes 1996; Pierre \& Peters 2000).
Erilaiset alustat voivat olla hyödyllisiä työkaluja tämän tehtävän toteuttamisessa. Alustoilla viitataan yleisesti sellaisiin rakenteisiin, joilla eri viiteryhmiä ja organisaatioita edustavat toimijat toteuttavat lisäarvoa tuottavaa toimintaa (Seppälä ym. 2015). Alustojen ideana on houkutella ja sitouttaa toimijoita tällaiseen toimintaan erityisesti verkostovaikutusten tuomilla hyödyillä (Ailisto ym. 2016, 14). Alustoille on tyypillistä myös se, että ne tarjoavat jonkinlaisen tilan, jossa toimijat voivat tunnistaa yhteisiä intressejä ja etsiä uusia yhteistyömahdollisuuksia (Sotarauta \& Suvinen, 2019). Toimijoiden lisäksi alustat keräävät yhteen erilaisia resursseja ja tarjoavat myös välineitä niiden käsittelyyn ja jäsentämiseen (Thomas ym. 2014, 202), minkä ansiosta alustat mukautuvat dynaamisesti ja itseohjautuvasti ympäristöönsä (Ciborra 1996).

Kun otetaan huomioon tällaiset alustoihin liittyvät piirteet, ne omaavat potentiaalia, jota voidaan hyödyntää myös kaupunkien hallinnassa, palvelutuotannossa ja kehittämisessä (Lember ym. 2019; Falco \& Kleinhans 2018). Näiden orastavien mahdollisuuksien pohjalta on alettu rakentaa ideaa uudenlaisesta kaupunkiyhteisöstä, jossa ihmiset voivat kokoontua alustoille jakamaan ideoitaan ja osaamistaan, etsimään kehittämismahdollisuuksia sekä käyttämään avointa dataa ja muita resursseja lisäarvoa tuottavaan toimintaan. Kaupunkien kohtaamiin haasteisiin voidaan näin hakea ratkaisuja yhteiskehittämisen keinoin ja hyödyntämällä kaupunkilaisten ja paikallisyhteisöjen tietoa ja osaamista innovatiivisten ratkaisujen synnyttämiseksi. (Anttiroiko 2016; Bollier 2016; Love 2015.) Samalla kun kunnat ja kaupungit soveltavat alusta-ajattelua, ne luovat siis pohjaa uudenlaiselle hallinnan mallille, joka puolestaan tuo tuoreita näkökulmia julkisen hallinnan paradigmaan (Janowski ym. 2018).

Alustan käsitteen soveltaminen hallinnon tutkimuksessa edellyttää kuitenkin sen mää- 
rittelyn tarkentamista. Käsite on laajentunut teknologiaorientoituneilta aloilta uusiin konteksteihin, mutta sen siirtymää tieteenalasta toiseen ei ole aina selkeästi muotoiltu (Thomas ym. 2014, 212) ja käsitteen merkitys kussakin kontekstissa määritellään harvoin (Offenhuber ym. 2019, 1567). Alustan käsitettä on kuvattu monitulkintaiseksi ja epäselväksikin (Gorwa 2019; Sotarauta ym. 2018) eikä sen määritelmästä ole päästy yksimielisyyteen (Larsson \& Andersson Schwarz, 2018, 119). Siihen liitetään usein myös erilaisia sivumerkityksiä ja mielikuvia, kuten vaikkapa avoimuus tai demokraattisuus, jotka eivät välttämättä määrittele kovinkaan osuvasti alustahallinnan realiteetteja (Nash ym. 2017; Gillespie 2010).

Tarkastelemme tässä artikkelissa, millaisen lisäarvon alustat tuovat kaupunkien hallintaan ja mitkä ovat tämän lisäarvon realisoitumisen yleiset edellytykset. Tarkastelemme tätä asiaa (1) suhteuttamalla paikallisen alustahallinnan erityispiirteet hallinnan paradigmoihin, (2) tunnistamalla alustoihin liitettyjä piirteitä paikallisen hallinnan konsepteissa sekä (3) lopuksi pohtimalla, miten hallinnan paradigmojen piirteet sekä alustoihin liitetyt mielikuvat näyttäytyvät eri tehtäviä toteuttavissa kaupunkialustoissa. Artikkelin tavoitteena on nostaa esiin näkökulmia, jotka ovat olennaisia, kun alustan käsitettä sovelletaan paikallisessa hallinnassa. Pyrimme tätä kautta lisäämään ymmärrystä siitä, miten alustahallinta on tarkoituksenmukaista käsitteellistää ja millaisia piirteitä alustojen hyödyntäminen tuo hallinnan teoriaan.

Artikkeli on luonteeltaan käsitteellis-teoreettinen ja sen metodologisen lähtökohdan muodostaa systemaattinen kirjallisuuskatsaus. Esittelemme seuraavassa luvussa lyhyesti artikkelin menetelmää ja aineistoa. Sen jälkeen pyrimme kiinnittämään paikallisen alustahallinnan laajempaan teoreettiseen keskusteluun kuvaamalla ensin alustan käsitteen laajenemista teknologiaorientoituneesta viitekehyksestä taloudelliseen, yhteiskunnalliseen ja erityisesti julkista hallintaa koskevaan keskusteluun. Tämän jälkeen analysoimme alustahallinnan suhdetta hallinnan teoriaan ja sitä, mitä uusia näkökulmia alustahallinta siihen tuo. Tästä siirrymme tarkastelemaan erilaisia alustan käsitteeseen liitettyjä mielikuvia, kuten avoimuutta ja osallisuutta ja sitä, mikä suhde niillä on alustadiskurssin osana syntynei- siin paikallisen alustahallinnan konsepteihin. Lopuksi konkretisoimme käsittelyä tyypittelemällä kaupunkien hyödyntämiä alustoja niiden tehtävien kautta ja arvioimalla, miten hallinnan paradigmojen piirteet ja alustoihin yhdistetyt mielikuvat liittyvät näihin eri alustatyyppeihin. Lopuksi vedämme yhteen artikkelin keskeisimmät johtopäätökset.

\section{AINEISTO JA MENETELMÄT}

Tämä artikkeli on olemassa olevaan kirjallisuuteen perustuva teoreettis-käsitteellinen analyysi. Osana taustatutkimusta tehtiin systemaattisen kirjallisuuskatsaus, jonka tarkoituksena oli selvittää, miten alustoja on käsitelty paikallistason julkisen hallinnon tutkimuksessa. Kirjallisuuskatsauksessa otettiin huomioon Andor-tietokannasta löytyvät, vuosien 20102020 välillä julkaistut, tieteelliset ja vertaisarvioidut englanninkieliset artikkelit, joissa hakusanoina käyttämämme sanat tai sanaparit oli määritelty artikkeleiden asiasanoiksi. Hakusanoina ja -sanapareina käytettiin: (platform ${ }^{\star}$ AND (public ${ }^{*}$ OR local ${ }^{\star}$ OR urban* OR city ${ }^{\star}$ OR cities $\left.^{\star}\right)$ ); (platform ${ }^{\star}$ AND governance ${ }^{\star}$ AND (public ${ }^{\star}$ OR city $^{\star}$ OR cities ${ }^{\star}$ OR urban* OR local $^{\star}$ )); (platform ${ }^{\star}$ AND service* AND (public ${ }^{\star}$ OR city ${ }^{\star}$ OR cities $^{\star}$ OR ecosystem ${ }^{\star}$ OR governance $\left.^{*}\right)$ ).

Havaitsimme kirjallisuuskatsauksessamme, että alustoista on kirjoitettu verrattain vähän paikallista hallintaa käsittelevässä tutkimuksessa. Haku tuotti 97 tulosta, joista vain 21 oli julkaistu hallinnon tai kaupunkitutkimuksen alan journaaleissa. Lopulliseen tarkasteluun valikoitui 46 artikkelia. Tarkastelun ulkopuolelle rajattiin artikkelit, jotka käsittelivät ainoastaan yksityisen sektorin toimijoita, joissa alustalla viitattiin johonkin hyvin rajattuun ilmiöön (esim. "brand strategy platform") tai jotka käsittelivät hallintoa ainoastaan kansallisvaltioiden tai kansainvälisten verkostojen tasolla. Yleisesti hallintoa eri tasoilla käsittelevät artikkelit kuitenkin otettiin mukaan tarkasteluun.

Kirjallisuuskatsausta on hyödynnetty kahdella tavalla. Ensinnäkin sen perusteella on tunnistettu keskeisiä teemoja, jotka on syytä ottaa huomioon, kun alustan käsitettä hyödynnetään paikallisessa hallinnassa. Näitä olivat erityisesti tarve käsitteenmäärittelyn selkiyttämiselle sekä 
alustahallintaan liitettyjen mielikuvien analysointi, sillä kirjallisuuskatsaus ei tuottanut yhtenäistä kuvaa alustan käsitteestä paikallisen hallinnan kontekstissa tai paikallisessa hallinnassa käytettyjen alustojen ominaisuuksista. Toiseksi kirjallisuuskatsauksen pohjalta on ryhmitelty induktiivisesti alustatyyppejä niiden funktioiden mukaan.

\section{ALUSTADISKURSSI: TEKNOLOGIASTA TALOUTEEN JA YHTEISKUNTAAN}

Tutkimus alustoista on viimeisen parin vuosikymmenen aikana lisääntynyt merkittävästi. Tutkimuskirjallisuuden kehityksessä on havaittavissa kaksi keskeistä trendiä. Ensinnäkin siinä missä tutkimus alustoista keskittyi aiemmin pääasiassa yksittäisten yritysten sisäisiin alustoihin, nykyisin alustat nähdään yhä useammin osana eri toimijoiden välisiä kompleksisia verkostoja (Thomas ym. 2014, 205). Toiseksi, vaikka alustan käsitteen juuret ovat teknologiaorientoituneilla aloilla, alusta-ajattelu on laajentunut uusille aloille (Thomas ym. 2014, 205; Baldwin \& Woodard 2009, 21).

Thomas ym. (2014) tutkivat alustoja käsittelevää tutkimuskirjallisuutta johtamisen kontekstissa. He tunnistivat laajassa systemaattisessa kirjallisuuskatsauksessaan neljä alustakirjallisuuden tutkimuksellista päähaaraa: tuoteperheiden näkökulma, alustat organisaatiorakenteena, alustaekosysteemit sekä alustat monisuuntaisilla markkinoilla. Tuoteperheiden näkökulma on tutkimussuuntauksista tutkituin (Thomas ym. 2014) ja ensimmäisenä kehittynyt (Baldwin \& Woodard 2009, 20-21; Seppälä ym. 2015, 4-5). Tässä tutkimussuunnassa alustoilla viitataan yritysten ja toimitusketjujen sisäisiin, erilaiset tuoteperheet mahdollistaviin teknologisiin standardeihin, jotka pohjautuivat tyypillisesti joko variointiin tai modulaarisuuteen (Thomas ym. 2014, 202-203; Seppälä ym. 2015, 4-5; Baldwin \& Woodard, 2009). Alustoja organisaatiorakenteina tarkastelevassa tutkimussuunnassa alustalla viitataan resursseja ja osaamista nopeasti yhteen kokoavaan ja järjestelevään organisaatioon (Thomas ym. 2014). Tällaisilla alustaorganisaatioilla ei ole pysyvää muotoa, vaan ne mukautuvat dynaamisesti ja itseohjautuvasti uusiin haasteisiin ja muuttuviin liiketoimintamahdollisuuksiin (Ciborra 1996).
Alustaekosysteemikirjallisuus puolestaan näkee alustat taloudellisten ekosysteemien solmuina tai kontrollipisteenä, jotka tuovat ekosysteemin toimijat yhteen (Thomas ym. 2014).

Alustat monisuuntaisilla markkinoilla on tutkimussuunnista tuorein (Baldwin \& Woodard 2009; Seppälä ym. 2015) ja nopeimmin kasvava (Thomas ym. 2014). Monisuuntaisilla markkinoilla alustat palvelevat kahta (two-sided markets) tai useampaa (multisided markets) asiakastyyppiä, joiden yhteyksistä syntyy suoria ja epäsuoria verkostovaikutuksia. Alustat huolehtivat osapuolten tuomisesta yhteen ja niiden välisten transaktioiden fasilitoimisesta. (Ailisto ym. 2016, 13.) Ne eivät kuitenkaan omista alustojen kautta välitettyjä tuotteita tai palveluja (Hagiu \& Yoffie 2009). Edellä mainitut tutkimussuunnat ovat limittyneitä ja erityisesti ekosysteemikirjallisuudella ja monisuuntaisten markkinoiden tutkimussuunnalla on monia yhteisiä piirteitä. Alustaekosysteemit nähdään yleensä monisuuntaisilla markkinoilla toimivan alustan ja sen ympärille rakentuneiden komplementaaristen sovellusten kokonaisuutena (esim. Tiwana 2014).

Alustat monisuuntaisilla markkinoilla on tutkimussuunnista lähimpänä sitä, mitä alustoilla arkikielessä tarkoitetaan. Arkipuheessa alustojen yhteydessä huomio kiinnittyy yleensä kaupallisiin, tietoaineistoja hyödyntäviin rakenteisiin, jotka yhdistävät palveluntarjoajia ja potentiaalisia asiakkaita, fasilitoivat transaktioita ja luovat arvoa hyödyntämällä käyttäjistä ja heidän käyttäytymisestään kerättyä dataa palvelujen kehittämisessä tai myymällä sitä eteenpäin (Larsson \& Andersson Schwarz 2018, 116). Tämä selittyy sillä, että alustojen kyky verkostovaikutusten synnyttämiselle perustuu useimmiten juuri monisuuntaisilla markkinoilla toimimiselle. Alustatalous kuvaa markkinaa, jossa alustoihin nojaava liiketoiminta on saavuttanut merkittävän tai määräävän markkina-aseman. (Ailisto ym. 2016, 13-14.) Siitä on tullut verrattain lyhyessä ajassa huomattava taloudellinen voima ja innovaation moottori (esim. Evans \& Gawner 2016).

Samalla tavoin kuin alustan käsite on levinnyt tiukasti teknologisesta ja pääosin yritysten ja toimitusketjujen sisäisestä kontekstista koko talousjärjestelmän tasolle, se on otettu käyttöön myös muiden alojen tutkimuksessa. Osa tut- 
kijoista on kiinnittänyt huomiota siihen, että alustat ja niihin liittyvät infrastruktuurit ovat 2000-luvun alkupuolelta asti rakentuneet kiinteäksi osaksi paitsi taloudellisia, myös sosiaalisia ja poliittisia järjestelmiä. Alustatalous on vaikuttanut merkittävästi yhteiskunnallisiin valtarakenteisiin sekä voimasuhteisiin alustojen ja perinteisten markkinatoimijoiden, julkisten toimijoiden sekä kansalaisten välillä. (van Dijck ym. 2018.) Samalla kun alustoille on siirtynyt suuri määrä erilaisia toimintoja, niille on kasaantunut myös huomattavasti taloudellista, poliittista, sosiaalista ja kulttuurista valtaa. Näihin yhteiskunnallisiin muutoksiin ja konteksteihin, joissa alustat ovat kiinteä osa yhteiskunnan rakenteita ja toimintaa, viitataan termillä alustayhteiskunta (engl. platform society) (van Dijck ym. 2018; de Waal ym. 2017; Nash ym. 2017).

Alustayhteiskunnassa monet arkiset asiat rakentuvat alustojen varaan. Näitä ovat esimerkiksi kaupankäynti, maksuliikenne, matkailu, media sekä yhä suuremmassa määrin vuorovaikutus eri muodoissaan. Samalla kun alustat ovat vakiinnuttaneet paikkansa vuorovaikutusta fasilitoivina rakenteina, ne ovat muovanneet sen normatiivisia ulottuvuuksia (Gorwa 2019). Tämä tekee näkyväksi alustojen luonteen sosiokulttuurisina ympäristöinä. Alustat esimerkiksi määrittelevät aktiivisesti, millaista sisältöä niihin voidaan jakaa. Nämä valinnat muokkaavat julkista keskustelua ja poliittista viestintää (Pasquale 2016; DeNardis \& Hackl 2015; Gillespie 2010). Alustojen sosiokulttuurinen ulottuvuus konkretisoituu paitsi siinä, miten alustat vaikuttavat sosiaaliseen todellisuuteen, myös siinä, miten sosiaalinen ympäristö vaikuttaa alustojen rakentumiseen. Vaikka jaetut standardit, protokollat ja spesifit teknologiset ratkaisut ovat alustojen luonteen kannalta tärkeitä, alustojen toiminta on kuitenkin sosiaalisen käyttäytymisen muovaamaa. (Offenhuber ym. 2019.)

Samalla kun alustoista on tullut kiinteä osa yhteiskunnallisia valtarakenteita ja sosiokulttuurista ympäristöä, alustan käsitettä on alettu käyttää yhä enemmän myös julkishallinnossa (esim. Brown ym. 2017). Alustayhteiskunnassa julkisen sektorin organisaatioiden roolia tarkastellaan osana alustaekosysteemejä, ei siis lähtökohtaisesti niitä kontrolloivana tai koordinoivana tahona (Plantin 2018, 256). Alustan käsite on tullut suosituksi myös paikallisessa hallinnassa, erityisesti innovaatiotoiminnan fasilitoinnissa (Borghys 2020; Anttiroiko 2016). Innovaatioalustat ovatkin vakiinnuttaneet paikkansa Suomen suurimpien kaupunkien strategioissa (6Aika 2015) ja alustaekosysteemejä käytetään yleisesti malliesimerkkeinä ja inspiraation lähteinä alueellisessa innovaatiopolitiikassa (Sotarauta \& Suvinen 2019).

Alustan käsitteen soveltaminen julkishallinnon kontekstissa edellyttää sen ymmärtämistä edellä kuvattujen tutkimussuuntien määritelmiä laajempana ilmiönä. Tämä koskee jopa hyvin perustavanlaatuisia piirteitä, kuten sitä, millaisissa ympäristöissä alustat toimivat. Teknologisia järjestelmiä ja monisuuntaisilla markkinoilla toimivia alustayrityksiä käsittelevissä määritelmissä alustojen nähdään usein toimivan ainoastaan digitaalisissa ympäristöissä. Esimerkiksi Tiwanan $(2014,7)$ mukaan alustat ovat ohjelmistopohjaisten järjestelmien laajenevia koodikantoja, jotka tarjoavat ydintoiminnot ja rajapinnat, joiden "päällä" järjestelmän varaan rakentuvat sovellukset toimivat. Kaupunkien hyödyntämät alustat toimivat kuitenkin usein ainakin osittain fyysisissä tiloissa, kuten esimerkiksi suurin osa Suomen kuuden suurimman kaupunkiseudun yhteisen 6Aika-strategian Avoimet innovaatioalustat -kärkihankeen aikana perustetuista alustoista (6Aika 2015) tai vaikkapa kaupunkilaisten organisoima Siivouspäivä, joka tuo ihmisiä yhteen julkisessa tilassa suorittamaan transaktioita kuntien luvalla (Siivouspäivä 2020). Määritelmät, jotka eivät rajaa ulos fyysisissä tiloissa toimivia alustoja, ovat siis paikallisen hallinnan kontekstissa käyttökelpoisimpia. Esimerkiksi Anttiroiko ym. $(2018,84)$ määrittelivät erityisesti kaupunkien hyödyntämät alustat näin: "Alustan käsite viittaa tässä [...] kontekstissa joukkoon erilaisia fasilitoivia järjestelyjä, jotka palvelevat sellaista taloudellista, poliittista tai sosiaalista toimintaa, joka tuottaa julkista arvoa kaupunkiyhdyskunnalle ja edistää erityisesti kaupunkien kehittämistehtävän toteuttamista."

Alustojen merkityksen kasvusta huolimatta, tietomme alustahallinnasta on toistaiseksi vielä melko vähäistä ja jäsentymätöntä. Seuraavaksi tarkastelemme alustahallintaa osana hallinnan teorioiden kehitystä. 


\section{ALUSTAHALLINTA SUHTEESSA HALLINNAN TEORIAAN}

Julkishallinnon kehityksen kuvataan yleisesti tapahtuneen länsimaissa kolmen vaiheen kautta; perinteisestä julkishallinnosta uuteen julkisjohtamiseen (New Public Management eli NPM) ja edelleen uuteen julkiseen hallintaan (New Public Governance eli NPG). Jokaiseen vaiheeseen liittyy elimellisesti tietty koordinaatiotapa, joka perinteisessä julkishallinnossa oli hierarkia, uudessa julkisjohtamisessa markkinat ja uudessa julkisessa hallinnassa verkostot (esim. Osborne 2010). Usein nämä vaiheet kuvataan ajallisesti eteneväksi prosessiksi, jossa uusi (ja parempi) julkisen johtamisen oppi syrjäyttää aiemman ja ongelmalliseksi todetun. Tämä on hallinnon uudistamisen dynamiikan näkökulmasta toimiva tulkinta, mutta useimpien julkisten organisaatioiden osalta on realistisempaa todeta, että kaikki kolme ovat erilaisin variaation mukana niiden hallinnassa. (Osborne, 2010.) Mutta miten alustahallinta suhteutuu tähän kokonaisuuteen?

Alustan toiminnan käynnistäminen ja hallinta vaatii jossain määrin sääntöjen asettamista ja niiden käytön valvontaa, mikä perustuu alustan ylläpitäjän/perustajan auktoriteettiin. Alustan ylläpitäjä voi äärimmäisenä keinona jopa sulkea käytön joiltakin osallistujilta, jos asetettuja sääntöjä ei noudateta. Hierarkkisten elementtien osuus on kaupunkien alustahallinnassa kuitenkin suhteellisen pieni. Auktoriteetin käyttäminen on pikemminkin keino, jota pyritään välttämään viimeiseen asti. Alustojen hallinnan "orkestrointina" tulisi perustua siihen, että tunnistetaan eri toimijoiden autonomia ja itseohjautuvuus. (Janssen \& Estevaz 2013; Lee \& Kwak 2012.)

Kaupunkien alustahallintaa voidaan sen sijaan hyvin perustein tarkastella markkinoina ja verkostoina - tai hieman kärjistäen - verkostomaisina markkinoina tai markkinamaisina verkostoina. Alustat kokoavat yhteen suuren määrän toimijoita ja yleisöä ilman välitöntä keskinäisriippuvuutta tai niin, että mukanaolijoilla olisi edes tietoa kaikista muista alustan toimijoista. Tämä ja alustan sisällä tapahtuvat vaihtosuhteet muistuttavat markkinoille tyypillisiä piirteitä ja alustoja kuvataankin usein markkinapaikoiksi, toreiksi tai basaareiksi (Raymond 1999). Vaikka voidaankin ajatella, että alustojen toiminnan koordinaatio on sekoitus sääntöjen, hintamekanismin ja vastavuoroisuuden mekanismeista, ne alustat, jotka menestyksekkäimmin voivat rakentaa yleisöjä, hyötyä yhteistyösuhteista ja skaalautua nopeasti suuremmiksi, seuraavat markkinoille tyypillistä hallintatapaa (Janssen \& Estevaz 2013). Uusia tulijoita alustalle houkuttelevat sen tarjoamat mahdollisuudet löytää asiakkaita, kumppaneita ja liittolaisia tai testata omia tuotteita tai ideoita.

Koordinaation termein markkinat perustuvat hintamekanismiin ja koordinaatio toimii näin "automaattisesti" ilman jonkin osapuolen aktiivista puuttumista (Williamson 1975). Yksilöllisesti motivoituneiden ja mahdollisuuksia hakevien toimijoiden itseintressi takaa järjestelmän tasapainon. Markkinat eroavat hierarkioista ja verkostoista, joihin kuuluu aina jonkun toimijan tietoinen pyrkimys koordinoida kokonaisuutta. Monissa alustoissa tämä tietoinen koordinaatio on melko pienessä roolissa ja ne toimivat enemmän markkinalogiikalla.

Kaupunkien hyödyntämillä alustoilla on myös monia hallintaverkostoille tyypillisiä piirteitä, kuten toimijoiden välinen suhde, julkisen arvon luomisen mekanismi ja järjestelmän avoimuus (esim. Anttiroiko 2016). Alustat kokoavat yhteen toimijoita (yleisö, asiakkaat, palveluntuottajat), joiden hallinnassa on erilaisia resursseja ja jotka tarjoavat yhteistoiminnan kautta mahdollisuuksia yhteiskehittämiseen, uuteen yritystoimintaan tai palveluihin (Anttiroiko ym. 2014). Toimijoiden välinen vuorovaikutus muistuttaa verkostotyyppistä yhteistoimintaa perustuessaan vapaaehtoisuuteen ja toimijoiden tasavertaisuuteen. Vaikka niiden toiminnassa näkyy markkinoihin liitetty ns. automaattinen koordinaatiomekanismi, alustojen ylläpitäjät myös orkestroivat erilaisia resursseja ja fasilitoivat transaktioita tavalla, joka muistuttaa verkostojohtamista (ks. Kronsell \& Mukhtar-Landgren 2018). Fasilitointia ja orkestrointia tarvitaan, jotta voidaan edistää erilaisia arvoja ja preferenssejä edustavien ja erilaisilla toimintalogiikoilla operoivien toimijoiden yhteistyötä. Diplomatia, neuvottelu ja suostuttelu - verkostojohtamiseen tyypillisesti liitettyinä toimintatapoina - ovat myös kaupunkien alustahallinnan olennaisia työvälineitä.

Yksinkertaisinta olisi määritellä alustahallinta hybridihallinnaksi, koska se kieltämättä si- 
sältää elementtejä kaikista edellä kuvatuista hallinnan malleista. Esimerkiksi konfliktien hallinnassa voidaan käyttää hierarkkista auktoriteettia, markkinoihin liitettyjä oikeustoimia tai verkostoissa käytettävää diplomatiaa.

Alustahallinnassa on kuitenkin myös joitakin piirteitä, jotka erottavat sen kaikista kolmesta yllä mainitusta hallinnan tyypistä (Janowski ym. 2018). Kun hierarkkisissa rakenteissa pääasiallisena toimijuuden perusteena on auktoriteetti ja sääntely, markkinoilla rationaalinen valinta ja verkostoissa keskinäisriippuvuus, alustoille hakeudutaan uusien mahdollisuuksien ja yhteyksien löytämiseksi ja yleisön rakentamiseksi. Alustoille on myös tunnusomaista avoin luonne ja nopean skaalautuvuuden mahdollisuus. Niihin ei niinkään liitytä keskinäisen riippuvuuden perusteella kuten verkostoihin, vaan niiden tarjoamien mahdollisuuksien vuoksi. Alustat ovat sosio-teknisiä tiloja, jotka on suunniteltu houkuttelemaan toimijoita (Nash ym. 2017). Jos alustat olisivat "vain verkostoja", niiden jäsenyys olisi tarkemmin määritelty ja stabiilimpi, ja jäsenten intressinä olisi toimia lähinnä verkoston jäsenten kanssa ilman yhteyttä laajempiin yleisöihin. Verkostoilla on jonkinlainen yhteinen tavoite tai nimittäjä, joka sitoo jäsenet yhteen. Alustoissakin on keskinäisriippuvuutta, mutta se kehittyy vasta alustojen toiminnan aikana, eikä ole pääsyy alustalle liittymiseen.

\section{OSALLISUUS JA AVOIMUUS ALUSTAHALLINNASSA}

Julkisen alustahallinnan on kuvattu olevan leimallisesti avointa ja osallistavaa (esim. Millard 2014; Janowski ym. 2014; Lee \& Kwak 2012). Juuri uudenlainen avoimuus ja osallistumisen mahdollisuudet voivatkin olla niitä teemoja, joissa alustahallinnan erityispiirteet suhteessa edellä kuvattuihin hallinnan paradigmoihin näkyvät parhaiten. Nämä piirteet korostuivat myös tekemässämme kirjallisuuskatsauksessa.

Kirjallisuuskatsauksessa kaupunkilaisten osallisuus oli keskeisessä roolissa alustoja käsittelevissä artikkeleissa erityisesti hallinnon ja kaupunkitutkimuksen alan journaaleissa. Alustahallinta yhdistetään usein suoraan tai osallistuvaan demokratiaan, jossa kaupunkilaisten muodostamat paikalliset verkostot luovat itse toimintaa ja viestivät hallinnolle, mitä asukkaat ja yhteisöt siltä odottavat (Brown ym. 2017; Bollier 2017; O’Reilly 2011). Nash ym. (2017, 372 ) ovat kuitenkin nostaneet esille kysymyksen siitä, parantaako alustamainen julkishallinto aidosti demokratiaa tai asukkaiden ja hallinnon välistä suhdetta sekä siitä, millaisia eroja eri väestöryhmien välillä on alustojen tarjoamien vaikutusmahdollisuuksien hyödyntämisessä. Alustat voivat olla hyvä keino osallistaa asukkaita päätöksentekoon, mutta käytännössä jo valmiiksi etuoikeutetut toimijaryhmät saattavat hyötyä alustojen tuomista mahdollisuuksista huomattavasti muita enemmän (Larsson \& Andersson Schwarz 2018, 126; Liu 2017; de Waal ym. 2017, 56; Desouza \& Bhagwatwar 2014, 46).

Ajatus alustojen demokratiaa tukevasta luonteesta ei ole vain julkishallinnon tarjoamiin alustoihin liitetty piirre. Myös kaupallisiin alustoihin yhdistetään usein positiivisia mielikuvia esimerkiksi avoimuudesta, tasapuolisuudesta ja neutraaliudesta. (Andersson Schwarz 2017; Nash ym. 2017; Gillespie 2010). Tällaisia alustan käsitteen saamia konnotaatioita on kuitenkin kyseenalaistettu. Kritiikki korostuu erityisesti silloin, kun alustoja tarkastellaan alustatalouden ja -yhteiskunnan viitekehyksessä eli koko järjestelmän tasolla. Tutkijat ovat havainneet, että alustataloudessa taloudellinen menestys ja sitä kautta valta keskittyvät usein pienelle joukolle suuria liiketoimintaekosysteemejä (van Dijck ym., 2018; Andersson Schwarz 2017; Jin 2015). Kenney ja Zysman (2016) ovat tuoneet esiin huolensa siitä, että suuret alustatoimijat voivat saada yliotteen globaalin talousjärjestelmän pelisääntöjen asettamisesta. Alustatalous voi esimerkiksi heikentää työntekijöiden asemaa, kun alustayrityksillä ei ole velvollisuutta tarjota perinteisten työmarkkinoiden kaltaisia etuja alustojen kautta työllistyville (Bollier 2016, 35). Vaikka alustat mielletään usein neutraaleiksi ympäristöiksi, tutkijat ovat todenneet, etteivät alustayritykset ole neutraaleja toimijoita (Andersson Schwarz 2017; Nash ym. 2017; de Waal ym. 2017; Pasquale 2016; Gillespie 2010, 350.) Suuret alustatoimijat ovat tuoneet lakien ja sosiaalisten normien lisäksi kaupunkilaisten jokapäiväiseen sosiokulttuuriseen ympäristöön itse määrittelemiään käyttöehtoja, normeja sekä teknisiä ja suunnittelullisia rajoituksia, jotka voivat ohjata käyttäjien toimintaa ja vuorovaikutusta (Gorwa 2019; DeNardis \& Hackl 2015). 
Lisäksi alustojen toiminta perustuu usein algoritmeille, jotka saatetaan mieltää objektiivisiksi, vaikka algoritmien on monissa yhteyksissä havaittu toistavan sosiaalisen ympäristön ennakkoluuloja (esim. Hajian ym. 2016). Alustan käsitteeseen liitetyt mielikuvat avoimuudesta, demokraattisuudesta ja tasavertaisuudesta voivat siis olla oikeastaan jopa harhaanjohtavia (Larsson \& Andersson Schwarz 2018, 126). Kenney ja Zysman (2016) kuvaavat alustayhteiskunnan yhtäältä demokratisoivien ja toisaalta keskittävien vaikutusten ristiriitaa kysymällä kärjistäen, onko alustayhteiskunnasta muodostumassa utopia vai dystopia - ja kenelle.

Alustahallintaa tarkasteltaessa on siis tärkeää ottaa huomioon merkitykset, joita alustan käsitteeseen on alettu liittää sen laajentuessa rajatusta määritelmästään teknologisessa viitekehyksessä uusiin konteksteihin. Yksi keskeinen alustoihin yhdistetty piirre on avoimuus, joka saa varsin erilaisia merkityksiä teknologisessa ja yhteiskunnallisessa viitekehyksessä. Alustojen avoimuutta arvioitaessa on erityisen tärkeää erottaa toisistaan arkkitehtoninen ja systeeminen avoimuus. Alustan arkkitehtoninen avoimuus viittaa komponenttien väljään yhteenliittämiseen (loose coupling), joka lisää rakenteen joustavuutta (Brown ym. 2017). Kaupungeille on esimerkiksi eduksi, että niiden hyödyntämien digitaalisten alustojen arkkitehtuurinen rakenne on mahdollisimman avoin, sillä se vähentää niiden riippuvuutta yksittäisistä palveluntarjoajista (Cuno ym. 2019). Thomas ym. (2014) havaitsivat kirjallisuuskatsauksessaan, että kaikkia heidän tunnistamiaan alustakirjallisuuden tutkimussuuntia yhdistää ajatus alustojen arkkitehtonisesta avoimuudesta. Kun taas tarkastellaan ekosysteemin normeja, sääntöjä, standardeja ja sopimuksia, ei kyse ole kuitenkaan varsinaisesti alustan arkkitehtuurista, vaan ennemminkin siitä, kuinka ekosysteemin suhteet rakentuvat ja miten sen päätöksenteko tapahtuu. Nimitämme tätä systeemiseksi avoimuudeksi. Larssonin ja Andersson Schwarzin (2018) mukaan alustat ovat suurilta osin keskitetyn valvonnan, keskitetysti luotujen normien ja keskitetysti määriteltyjen arvojen alaisia, jolloin systeemisen avoimuuden taso on matala. Systeemisen avoimuuden aste alustoilla kuitenkin vaihtelee: osassa alustoista alustantarjoaja on vastuussa koko ekosysteemin sääntöjen asettamisesta, kun taas toisissa ekosysteemin standardit, protokollat ja sopimukset ovat toimijoiden yhdessä kehittämiä (Brown ym. 2017, 170). Päätöksentekovalta alustaekosysteemien sisällä voi olla keskittynyttä erityisesti silloin, kun alustan tarjoaa vain yksi toimija (Hein ym. 2019).

Alustahallinnan kuvataan siis olevan avointa ja lisäävän osallisuutta sekä vaikutusmahdollisuuksia, mutta toisaalta on havaittu, että alustojen toimintaan voi liittyä sosiaalista selektiivisyyttä ja päätöksenteon keskittyneisyyttä. Alustahallinnan avoimuus voi jäädä näennäiseksi erityisesti silloin, jos huomio kiinnitetään ainoastaan alustojen arkkitehtoniseen avoimuuteen. Alustan käsitteeseen liitettyjä mielikuvia ei kannata omaksua varauksetta alustahallinnan ominaisuuksiksi, vaan niiden toteutumista on parasta arvioida erikseen eri yhteyksissä. Seuraavaksi tarkastelemme, miten edellä esitetyt julkiseen alustahallintaan ja alustan käsitteeseen liitetyt mielikuvat erityisesti avoimuudesta ja osallisuudesta näyttäytyvät paikallisen hallinnan viitekehyksessä. Kuvaamme ensin niiden roolia alustamaista hallintoa korostavissa paikallisen hallinnan käsitteellisissä konsepteissa ja sitten konkreettisemmalla tasolla erilaisilla kaupunkien hyödyntämillä alustatyypeillä.

\section{ALUSTOJEN PIIRTEET PAIKALLISEN HALLINNAN KONSEPTEISSA}

Tarkastelemme avoimuuden ja osallisuuden kaltaisia alustoihin liitettyjä mielikuvia paikallisen hallinnan konsepteissa kolmen esimerkin kautta: kaupunkialusta paikallisen hallinnan ideaalimallina, kaupunki alustana ja hakkeroitava kaupunki. Kaupunkialusta (Urban Platform) on yksi neljästä Hendriksin (2014) tunnistamasta kaupunkien hallinnan ideaalimallista. Kaupunkialustan konsepti otettiin mukaan tarkasteluun, sillä alustamaiseen paikalliseen hallintaan liitetyt mielikuvat tulevat erityisen hyvin esiin, kun sitä suhteutetaan muihin paikallisen hallinnan ideaalimalleihin. Kaksi muuta konseptia lähestyvät alustahallintaa pragmaattisemmista lähtökohdista. City as a Platform (CaaP) eli 'kaupunki alustana' oli luonteva valinta tarkasteluun, sillä se on selvästi tunnetuin kaupunkien alustahallintaa kuvaava konsepti. Hackable City eli 'hakkeroitava kaupunki' muistuttaa CaaP-konseptia, mutta tarjoaa sille hyvän ver- 
tailukohdan, sillä se painottaa alustan käsitteeseen liittyviä mielikuvia eri näkökulmasta.

\section{Kaupunkialusta}

Hendriks (2014) ryhmittelee kaupunkien hallinnan kenttää kahden päätöksenteon akselin avulla. Toinen akseli on painotus joko tavallisiin kansalaisiin eli ikään kuin alhaalta ylöspäin suuntautuvaan päätöksentekoon tai päätöksentekijöihin eli hierarkkisesti ylhäältä alaspäin suuntautuvaan päätöksentekoon. Toinen akseli puolestaan jakaantuu integroivaan deliberatiiviseen keskusteluun ja "valikoivaan valintaan". Integroiva deliberatiivinen keskustelu edustaa verkostohallintaan liitettyjä piirteitä, kuten konsensushakuisuutta ja moniäänistä päätöksentekoa, kun taas valikoiva valinta painottaa kilpailullisuutta. Näiden akseleiden pohjalta Hendriks (2014) rakentaa neljä hallinnan ideaalimallia:

1. Kaupungin hallintakoalitio (Urban Regime)

2. Urbaanit markkinat (Urban Market)

3. Urbaani edustajisto (Urban Trust) ja

4. Kaupunkialusta (Urban Platform)

Hendriksin (2014) mallissa kaikkein keskittynein päätöksentekomalli on päätöksentekijöitä ja valikoivaa valintaa korostava hallintakoalitio. Kaikkein hajautetuin päätöksentekomalli puolestaan on kansalaislähtöisyyttä ja integroivaa deliberatiivista keskustelua korostava kaupunkialusta. Kaupunkialusta on markkinoita deliberatiivisempi, mutta eroaa myös verkostojen varaan rakentuvasta päätöksentekomallista, sillä eri intressitahojen edustajien sijaan yksittäisten kansalaisten ääni tulee paremmin kuuluviin. Tässä typologiassa alustahallinta näyttäytyy siis korostetun avoimena, osallistavana, kansalaislähtöisenä ja demokraattisena.

\section{City as a Platform}

Kaupunki alustana on konsepti, joka pyrkii jäsentämään alustojen merkityksen kasvun ja kaupunkien hallinnan suhdetta. Sillä on vahva teknologinen perusta, sillä sen keskeinen ajatus on, että alustat yhdistävät yhteentoimivasti kaupunkien digitaaliset infrastruktuurit, tietojärjestelmät sekä datan, joka kaupungeissa syntyy ja jota kaupungit tarvitsevat niin palvelujen järjestämisessä kuin toimiessaan laajemmissa verkostoissa (Anttiroiko ym. 2018; Anttiroiko 2016). Alustakehitys yhdistyy tätä kautta yhteen kaupunkikehittämisen suuntaa määrittäneeseen käsitteeseen, älykkääseen kaupunkiin, jonka ideana on valjastaa teknologinen kehitys parantamaan kilpailukykyä, tehokkuutta, elämänlaatua ja kestävyyttä (Anttiroiko 2016, 5). Tässä yhteydessä korostuu avoimen datan merkitys, sillä se mahdollistaa uusia potentiaalisesti skaalautuvia innovaatioita. Bollier $(2016,33)$ toteaakin talouskasvun vauhdittamisen, tuottavuuden parantamisen ja työpaikkojen lisäämisen olevan yksi CaaP-konseptin keskeisimmistä tavoitteista.

CaaP ei kuitenkaan pelkisty digitaalisiin infrastruktuureihin tai arkkitehtoniseen avoimuuteen, vaan muuttaa myös perusajatusta kaupunkien toimintalogiikasta. Toinen sen toimintalogiikkaa määrittävä ulottuvuus liittyy nimittäin osallistavuuteen, asukaslähtöisyyteen ja kaupunkilaisten omaehtoiseen toimintaan. Tämä näyttäytyy siten, että kaupunkiyhdyskunnan ongelmiin vastataan kollektiivisesti alustoilla, joille ihmiset kerääntyvät jakamaan ideoita, hyödyntämään resursseja ja muotoilemaan ratkaisuvaihtoehtoja. Ratkaisuja haetaan siis yhteiskehittämällä sen sijaan, että ne suunniteltaisiin keskitetysti byrokraattisen, siiloihin jakautuneen ja asiantuntijoiden roolia korostavan hallinnon puitteissa. (Anttiroiko 2016; Bollier 2016.) Tämä ulottuvuus näyttäisi siis heijastelevan alustahallintaan liitettyä ajatusta osallistuvasta demokratiasta.

\section{Hakkeroitava kaupunki}

Hakkeroitava kaupunki on de Waalin ja kumppaneiden (2017) käyttämä alustalogiikalla toimivaa kaupunkia kuvaava termi. Heidän mukaansa erilaiset systeemitasoiset hallintajärjestelmät vaikuttavat siihen, kuinka "hakkeroitava" kaupunki lopulta on. Vaikka CaaP-konseptin taustalla on ajatus kaupungin voimasuhteiden uudelleenjärjestämisestä, sen päähuomio kohdistuu erityisesti asukaslähtöisyyden ja monitoimijaisuuden avulla vahvistettuun innovatiivisuuteen ja sitä kautta kaupungin kilpailukykyyn, kun taas hakkeroitavan kaupungin keskiössä on eksplisiittisesti kaupunkilaisten omaehtoisuus, itseorganisoituminen ja eräänlainen "tee-se-itse -kulttuuri" sekä hallinnon läpinäkyvyys ja joustavuus. Konseptin ytimessä on kysymys siitä, 
miten digitaaliset alustat voivat tarjota mahdollisuuden systeemiselle muutokselle, joka lopulta avaa instituutioita ja infrastruktuureja sekä niihin liittyvää päätöksentekovaltaa tavallisten kaupunkilaisten ulottuville (de Waal ym. 2017). Alustoihin liitetyt mielikuvat osallisuuden lisäämisestä, hajautetusta päätöksenteosta ja alustojen demokratisoivasta vaikutuksesta ovat siis hyvin voimakkaasti esillä hakkeroitavan kaupungin konseptissa.

\section{Avoimuus ja osallisuus kaupunkien alustahallinnan konsepteissa}

Alustoihin liitetyt mielikuvat niin arkkitehtonisesta kuin systeemisestäkin avoimuudesta, osallisuuden parantamisesta, asukaslähtöisyydestä, moniäänisyydestä ja tasapuolisuudesta heijastuvat selvästi edellä kuvattuihin paikallisen hallinnan konsepteihin. Sen lisäksi, että alustat ymmärretään osallisuutta tukevina rakenteina, alustahallinnalla katsotaan myös olevan jopa ympäröivää yhteiskuntaa demokratisoiva vaikutus. Tällainen näkemys voi kuitenkin piirtää turhan yksipuolisen kuvan alustoista ja niiden hallinnasta, sillä todellisuudessa päätöksenteko alustoilla voi olla myös keskitettyä ja alustaekosysteemit toimivat usein markkinaehtoisesti, jolloin toimijakenttä mukautuu ympäristöönsä kannattavuuden perusteella, eikä toimijoiden välisiä suhteita välttämättä määritellä deliberatiivisesti. Edellä esitettyjen konseptien avulla voidaan kuitenkin hahmottaa näkemyksiä siitä, millaista paikallinen alustahallinta parhaimmillaan voi olla. Siihen, miten alustahallinnan piirteet ja siihen liitetyt mielikuvat konkretisoituvat kaupunkien toiminnassa, vaikuttavat esimerkiksi alustojen erilaiset funktiot, joita käsitellään seuraavaksi.

\section{PAIKALLINEN HALLINTA ERITYYPPISILLÄ ALUSTOILLA}

Koska alustan käsitteen juuret ovat teknologiaorientoituneilla aloilla ja alustataloudessa, alustojen määritelmät korostavat pääsääntöisesti digitaalisia, monisuuntaisilla markkinoilla toimivia kaupallisia transaktioalustoja. Ajatus monisuuntaisista markkinoista toistuu tietyllä tavalla myös kaupunkien tarjoamilla alustoilla, sillä niiden lähtökohtana on usein kahden tai useamman toimijaryhmän tuominen yhteen ja rajapintana toimiminen näiden välillä. Kaupunkien hyödyntämät alustat eivät kuitenkaan välttämättä, tai edes useimmiten, vaikuta perustuvan transaktioiden fasilitoimiseen vaan ne palvelevat erityyppisiä funktioita. Tämä merkitsee sitä, että edellisessä luvussa käsiteltyjä geneerisiä kaupunkialustakonsepteja on tarkennettava, jotta niistä saadaan tuotettua riittävän nyansoitu kuva. Keskeistä tässä on se, että alustojen funktiot vaikuttavat siihen, miten hallinnan paradigmojen piirteet sekä alustoihin liitetyt mielikuvat, kuten avoimuus ja osallisuus, niillä näkyvät.

Alustoja on luokiteltu niiden funktion mukaan (ks. esim. Nooren ym. 2018; Evans \& Gawner 2016), mutta olemassa olevat typologiat eivät kuvaa kovin kattavasti julkiselle sektorille tyypillisistä alustatyyppejä. Siksi olemme jäsentäneet kirjallisuuskatsaukseemme perustuen kaupunkien hyödyntämiä alustoja niiden funktion mukaan. Olemme tunnistaneet neljä eri alustatyyppiä: palvelualustat, innovaatioalustat, osallisuusalustat ja avoimen julkisen datan alustat.

\section{Palvelualustat}

Julkisia palveluita tarjoavat alustat tuovat yhteen palveluntarjoajia ja asiakkaita eli toimivat monisuuntaisilla markkinoilla. Ne hyödyntävät alustojen toimintalogiikkaa liiketoimintamallina ja muistuttavat näin yksityisten markkinoiden transaktioalustoja ja "verkostomaisia markkinoita". Ranerup ym. (2016) lukevat näihin palvelualustoihin myös näennäismarkkinoilla toimivat eli julkisin varoin subventoidut yksityisomisteiset alustat. Keskeinen ajatus tässä palvelujen järjestämisen tavassa on, että kansalaiset saavat vapaasti valita palvelun tuottajan keskenään kilpailevien toimijoiden joukosta. Julkisen palvelun alustat konkretisoivat näin hallinnan paradigmoista erityisesti uuden julkisjohtamisen roolia alustahallinnassa. (Ranerup ym. 2016.) Julkisen sektorin tavoitteena palvelujen siirtämisessä digitaalisille alustoille voi olla palvelujen tuottamisen tehostaminen, niihin pääsyn sujuvoittaminen tai esimerkiksi asiakkaiden auttaminen löytämään heille sopivin palveluntuottaja.

Jos palvelualustalla tuotetaan palveluja yhdessä kaupunkilaisten kanssa (co-production), ne voivat toimia myös osallistavina rakenteina. Tällöinkin niiden toiminnan taustalla on ajatus 
paremmasta taloudellisesta kannattavuudesta ja vaikuttavuudesta: kaupunkiorganisaation ja kaupunkilaisten resursseja käytetään tehokkaammin ja tuotetaan yksilöllisempiä palveluja. (Falco \& Kleinhans 2018; Lulin 2017; Bovaird \& Loeffler 2012.) Palvelualustat ovat ehkä suoraviivaisin tapa, jolla kaupungit ovat osa alustayhteiskuntaa, mutta ei suinkaan yleisin. Julkisten palvelujen siirtämisen alustoille voikin olla yksi strateginen tapa olla edelläkävijä alustataloudessa (Auvinen 2018).

\section{Innovaatioalustat}

Alustaperusteisista innovaatioekosysteemeistä on tullut suosittu tarkastelukehikko innovaation fasilitoinnille kaupungeissa. Tämä lähestymistapa keskittyy alustojen kykyyn yhdistää erilaisia, mutta toisiinsa liittyviä toimijoita, toimintoja ja tietovarantoja. (Borghys ym. 2020.) Innovaatioekosysteemejä korostavassa alueellisessa innovaatiopolitiikassa alustat ovat sosio-teknisiä ympäristöjä, joiden avulla pyritään ekosysteemien vahvistamiseen, alueellisen elinkeinorakenteen uudistamiseen ja viime kädessä taloudelliseen menestykseen. Käytännössä innovaatioalustat voivat esimerkiksi palvella yhteiskehittämishankkeita, tarjota mahdollisuuksia Living Lab -tyyppisille projekteille tai tuoda relevantteja toimijoita, kuten vaikkapa osaajia, yrittäjiä ja rahoittajia yhteen uuden liiketoiminnan synnyttämiseksi. Ne toimivat usein ainakin osittain fyysisissä tiloissa.

Verrattuna aiempiin, hierarkkisempiin innovaatiopolitiikkoihin, ekosysteemejä ja alustoja korostava innovaatiopolitiikka painottaa enemmän markkinamekanismeja (Sotarauta \& Suvinen 2019), joten innovaatioalustojen hallintaan liittyy uuden julkisjohtamisen elementtejä. Siinä on kuitenkin huomattavasti yhtäläisyyksiä myös uuden julkisen hallinnan paradigman kanssa, sillä alustojen varaan rakentuvissa innovaatioekosysteemeissä kaupunki mielletään usein yhtenä toimijana verkostossa muiden joukossa ja sen rooli on tyypillisesti fasilitoiva (Borghys ym. 2020; Anttiroiko 2016). Verrattuna palvelualustoihin, innovaatioalustat toimivat verkostomaisemmin ja niitä voisikin yksinkertaistaen luonnehtia "markkinamaisiksi verkostoiksi".

Innovaatioalustat ovat keskeinen osa erityisesti City as a Platform -konseptia, jossa osalli- suus ja innovaatiotoiminnan demokratisoiminen ovat keskeisiä teemoja, mutta kaupunkien perimmäinen tavoite innovaatioalustoilla toimimiselle on kuitenkin lähtökohtaisesti elinkeinotoiminnan ja talouskasvun edistäminen. (Bollier 2016; Anttiroiko 2016.)

\section{Osallisuusalustat}

Osallisuusalustojen tarkoitus on lähtökohtaisesti parantaa kaupunkilaisten mahdollisuutta vaikuttaa ympäristöönsä osallistamalla heitä päätöksentekoon ja kaupungin toimintaan. Tämä pyrkimys kuvastaa alustahallintaan liitettyä ajatusta osallistuvan demokratian ja kaupunkilaisten vaikutusmahdollisuuksien lisäämisestä.

Kuten innovaatioalustoilla, myös osallisuusalustoilla kaupunkilaisten tieto, kokemusasiantuntijuus ja osaaminen tunnistetaan arvokkaaksi ja sitä halutaan hyödyntää. Osallisuusalustatkin voivat mahdollistaa innovaatioita, mutta niiden taustalla on ajatus yhteiskunnallisesta muutoksesta kohti vahvempaa kansalaisyhteiskuntaa ja systeemistä avoimuutta. Alustoihin liitetyt mielikuvat esimerkiksi demokraattisuudesta näkyvät siis eniten juuri osallisuusalustan ideassa. Innovaatioalustojen tapaan osallisuusalustoilla kaupunkiorganisaation rooli on korostetusti mahdollistava. Kaupunki voi olla alustantarjoaja, mutta osallisuusalustat voivat olla myös kaupunkilaisten itse perustamia. (esim. Falco \& Kleinhans, 2018). Osallisuusalustat sopivat siis hyvin CaaP-konseptiin ja erityisesti ajatukseen hakkeroitavasta kaupungista, jossa alustojen nähdään edistävän systeemistä muutosta, joka tuo päätösvaltaa tavallisten kaupunkilaisten ulottuville (vrt. de Waal ym. 2017). Etenkin kaupunkilaisten itse organisoimat alustat ovat keskeisiä omaehtoisuutta korostavassa hakkeroitavan kaupungin konseptissa. Osallisuusalustat toimivat asukasrajapinnassa ja parhaassa tapauksessa perustuvat integroivaan deliberatiiviseen keskusteluun eli ne muistuttavat myös Hendriksin (2014) näkemystä kaupunkialustasta hallinnan ideaalimallina. Alustahallinnassa osallisuusalustoilla onkin paljon verkostohallintaan liitettyjä piirteitä ja se muistuttaa siten hallinnan paradigmoista eniten uutta julkista hallintaa.

On kuitenkin tärkeää huomata, että osallisuuden aste osallisuusalustoilla voi vaihdella huomattavastikin (Falco \& Kleinhans, 2018; Desouza 
\& Bhagwatwar 2014). Osallisuusalustat voivat perustua yksinkertaisesti asukkaiden konsultointiin vaikkapa kaupunkikehittämishankkeissa tai ne voivat luoda kaupunkilaisille myös suorempia vaikuttamismahdollisuuksia tarjoten ympäristön, jossa asukkaat voivat itse tuottaa ratkaisuja paikallisiin, tärkeiksi kokemiinsa kysymyksiin (Desouza \& Bhagwatwar 2014). Ratkaisuja voidaan kehittää kollektiivisesti esimerkiksi osallistavaa budjetointia hyödyntäen. Vaikka osallisuusalustat ovat periaatteessa kaikille avoimia, ne voivat kuitenkin olla osalle ihmisryhmistä helpommin saavutettavissa kuin toisille, joten niiden mahdolliseen sosiaaliseen selektiivisyyteen on kiinnitettävä erityistä huomiota (Liu 2017; de Waal ym. 2017; Desouza \& Bhagwatwar 2014).

\section{Avoimen julkisen datan alustat}

Avointa julkista dataa tarjoavat alustat (Open Governance Data platforms eli OGD-alustat) ovat yleistyvä alustatyyppi. OGD-alustat ovat digitaalisia arkkitehtuureja, jotka on suunniteltu tarjoamaan asukkaille, yrityksille ja muille toimijoille mahdollisuus käyttää julkishallinnon dataa ja hyödyntää sitä arvonluontiin. Hallinnon rooli näillä alustoilla on olla mahdollistaja ja fasilitoija ylläpitämällä alustaa ja tekemällä päätöksiä datan avaamisesta. (Danneels ym. 2017.) OGD-alustat voivat olla kansallisia, kaupunkien tarjoamia tai kaupunkien yhteisiä, kuten esimerkiksi Helsinki Region Infoshare (ks. Helsinki Region Infoshare 2017). Julkisen datan avaamisen taustalla on ajatus hallinnon läpinäkyvyyden ja tilivelvollisuuden parantamisesta, mutta toisaalta myös innovaation edistämisestä, sillä datalla nähdään olevan lisäksi sosiaalista ja kaupallista arvoa (Attard ym. 2015).

Avoimen julkisen datan alustoilla on yhtymäkohtia palvelu-, innovaatio- ja osallisuusalustoihin. Ensinäkin, datan avaaminen vapaaseen käyttöön voidaan ymmärtää julkisen sektorin tarjoamana palveluna. OGD-alustat eivät kuitenkaan välttämättä toimi monisuuntaisilla markkinoilla, vaan informaatiovirrat ovat usein yhdensuuntaisia tiedon siirtyessä julkiselta sektorilta muille toimijoille (Danneels ym. 2017). Toiseksi, OGD-alustat mahdollistavat uusia potentiaalisesti skaalautuvia innovaatioita ja luovat edellytyksiä kaupungin taloudelliselle uudistumiselle ja menestykselle, joten niillä on läheinen suhde alustojen roolia korostavaan innovaatiopolitiikkaan. Niiden generoima innovaatio ei kuitenkaan lähtökohtaisesti perustu toimijoiden tuomiseen yhteen, vaan resurssien eli datan hyödyntämiseen. Kolmanneksi, OGDalustat luovat mahdollisuuksia asukkaiden ja yhteisöjen omaehtoiseen toimintaan. Esimerkiksi Desouza ja Bhagwatwar (2014) käsittelivät niitä yhtenä osallisuusalustojen arkkityyppinä. Heidän analysoimissaan tapauksissa avointa julkista dataa tarjoavat alustat mahdollistivat kuitenkin samalla myös asukkaiden välisen tiedonvälityksen ja jalostuksen eli ne toivat yhteen monia eri toimijoita. Vaikka julkisen sektorin datan avaaminen voi siis olla osa niin innovaatio- kuin osallisuusalustaekosysteemiä ja datan tarjoaminen voidaan mieltää palveluksi, OGDalustoilla on piirteitä, jotka erottavat ne edellä mainituista alustatyypeistä.

Avoimen datan tarjoaminen on hyvä esimerkki siitä, miten alustahallintaan liitetty mielikuva avoimuudesta voi toteutua käytännössä. Se on keskeinen resurssi älykkään kaupungin kehittämisessä ja olennainen osa myös CaaP-konseptia (Anttiroiko 2016). Se on niin ikään tärkeä elementti mielikuvassa hakkeroitavasta kaupungista, sillä se lisää hallinnon läpinäkyvyyttä ja siten systeemistä avoimuutta. Kuten muissakin alustatyypeissä, kaupungin rooli OGD-alustoilla on toimija mahdollistajana. O'Reilly (2011) on pitänyt avoimen datan yleistymistä tekijänä, joka sellaisenaan edistää hallinnon kykyä ymmärtää itsensä "alustana".

\section{Monipuolisempi kuva paikallisesta alustahallinnasta}

Tarkastelemalla alustahallintaa erityyppisillä kaupunkien hyödyntämillä alustoilla, voidaan saavuttaa monipuolisempi kuva siitä, miten eri hallinnan paradigmat ja alustoihin liitetyt mielikuvat realisoituvat käytännön alustahallinnassa, sillä hallinnan mekanismit näyttäytyvät erityyppisillä alustoilla erilaisina yhdistelminä. Markkinoihin ja eritoten verkostoihin perustuvat hallinnan mallit ovat pääsääntöisesti korostetussa asemassa. Asian voi tiivistää siten, että osa alustaekosysteemeistä vaikuttaa enemmän verkostomaisilta markkinoilta, kun taas toiset näyttävät enemmän markkinamaisilta verkos- 
toilta. Alustahallintaan liittyvät riskit, kuten alustojen mahdollinen sosiaalinen selektiivisyys ja olemassa olevien syrjivien rakenteiden toistaminen erityisesti osallisuusalustoilla kuitenkin alleviivaavat tarvetta myös jonkinasteiselle paikalliselle sääntöihin perustuvalle koordinaatiolle.

\section{JOHTOPÄÄTÖKSET}

Kaupungeilla on erityinen rooli alustayhteiskunnassa, sillä sen lisäksi että erilaiset kaupalliset alustat ovat vahvasti näkyvissä urbaaneissa ympäristöissä, kaupunkiorganisaatiot hyödyntävät myös itse alustoja ja alustahallintaa. Alustan käsitteen käyttö on levinnyt teknologisesta kontekstista osaksi talouden järjestymistä, yhteiskunnallisia valtarakenteita sekä sosiokulttuurista ympäristöä ja siten tullut oleelliseksi myös hallinnon tutkimuksessa. Käsitteen merkitysten siirtymää tieteenalasta toiseen ei kuitenkaan ole aina selkeästi muotoiltu (Thomas ym. 2014). Olemme tässä artikkelissa tarkastelleet alustan ja alustahallinnan käsitteiden saamia merkityksiä ja mielikuvia erityisesti paikallisen hallinnan kannalta.

Olemme havainneet alustoihin avoimuuteen ja osallisuuden vahvistamiseen yhdistettyjen mielikuvien heijastuvan selvästi paikallisen alustahallinnan konsepteihin. Alustan käsitteeseen liitettyjä konnotaatioita ei kuitenkaan ole syytä omaksua täysin kritiikittömästi, sillä ne voivat olla jopa harhaanjohtavia. Käsitettä käytettäessä, olivatpa kyseessä sitten akateeminen tutkimus tai paikallisen hallinnan käytännöt, tulisikin aina pohtia, mihin sillä tosiasiallisesti viitataan, millaisia mielikuvia se välittää osallistujille ja mitkä ovat sen pohjalta muotoiltujen hallinnan rakenteiden ja prosessien todelliset vaikutukset paikallisten toimijoiden osallisuuteen ja valtasuhteisiin.

Olemme todenneet, että alustahallinnassa yhdistyy niin verkostojen kuin markkinoidenkin ominaisuuksia sekä jossain määrin myös hierarkioiden piirteitä. Kun analysoidaan, toimivatko alustat kuten "markkinaehtoiset verkostot" vai "verkostomaiset markkinat", on otettava huomioon alustan tyyppi, tarkastelun taso sekä yhteiskunnallinen konteksti. Alustatyyppi vaikuttaa siihen, miten paradigmojen piirteet ja erityisesti markkinaehtoisuus näyttäytyvät alus- tahallinnassa. Paikallisen hallinnan yhteydessä on syytä erottaa toisistaan palvelu-, innovaatioja osallisuusalustat sekä julkisen datan alustat, sillä ne palvelevat eri tarkoituksia, toimivat eri toimintalogiikalla ja kantavat alustoihin liitettyjä mielikuvia eri tavoin. Tarkastelun tasoa vaihtamalla taas alustahallinnan keskittyneisyyden ja hajaantuneisuuden aste voi näyttää varsin erilaiselta. Tarkastelun tasona voi olla yksittäinen alusta, alustaekosysteemi, kaupunki alustana tai laajemmin koko alustayhteiskunta. Yhteiskunnallisella kontekstilla taas on oma merkityksenä, sillä sen lisäksi, että alustat vaikuttavat yhteiskuntaan ja sen sosiokulttuurisiin piirteisiin, sosiaalinen ympäristö vaikuttaa siihen, millaisiksi alustat rakentuvat (Offenhuber ym. 2019). Esimerkiksi avoimuus on yksi alustoihin useimmin liitetyistä mielikuvista, mutta se voi viitata joko arkkitehtoniseen tai systeemiseen avoimuuteen. Systeeminen avoimuus vaikuttaa voimakkaasti siihen, miten alustan käsitteen arvolataukset todellisuudessa realisoituvat.

Siitä huolimatta, että hierarkiat koordinaatiokeinona ovat alustahallinnassa pienehkössä roolissa, alustojen hallinta edellyttää yhteisiä sääntöjä. Alustoilla normien asettaminen perustuu yleensä alustan ylläpitäjän tai perustajan auktoriteettiin. Silloinkin, kun kaupungit eivät ole tässä asemassa, niillä voi julkisen sektorin organisaatioina olla tarve valvoa yhdenvertaisuuden kaltaisten julkisten arvojen toteutumista alustaekosysteemeissä, joissa ne ovat mukana. Tämä edellyttää tietoista pyrkimystä osallistua alustaekosysteemin päätöksentekoon. Alustat ovat itseohjautuvia rakenteita, mutta se ei tarkoita, etteikö niiden toimintaan voisi tai kannattaisi pyrkiä vaikuttamaan. Jotta monimutkaisiin alustaekosysteemeihin voitaisiin vaikuttaa, on tunnettava niiden toimintalogiikkaa. Tästä syystä alustahallinnan tutkiminen ja osaamisen lisääminen olisi ensiarvoisen tärkeää.

Vaikka olemme havainneet alustahallinnassa ominaisuuksia hallinnan paradigmoista, sillä on myös niistä eroavia perustavanlaatuisia piirteitä, jotka on syytä ottaa huomioon hallintateoreettisessa keskustelussa. Ensinäkin alustahallinnassa korostuu erityisesti erilaisten toimijoiden tuominen yhteen uusien mahdollisuuksien ja ratkaisujen löytämiseksi. Toisin kuin verkostoissa, pääsyy alustoille liittymiseen ei siis ole olemassa oleva keskinäisriippuvuus, vaan yhteistyölle et- 
sitään mahdollisuuksia ja keskinäisriippuvuudet voivat jäädä löyhiksi ja kehittyvät vasta alustojen toiminnan aikana. Toinen alustahallinnalle leimallinen piirre on asukkaiden omaehtoisen toiminnan mahdollistaminen ja heidän osaamisensa hyödyntäminen. Vaikka myös erilaiset aiemmat verkostohallinnan muodot edistävät yhteistyötä hallinnon ja kansalaisten välillä, ne eivät alustahallinnan tavoin korosta julkisorganisaatioiden pyrkimystä tarjota sellaista dataa, välineistöä ja koordinaatiota, jolla voimaannutetaan kuntalaisia luomaan itse julkista arvoa (Janowski ym. 2018). Kolmanneksi, julkinen ar- vo syntyy alustoilla monimuotoisesta toimijoiden ja toimintojen yhdistämisestä, tarvittaessa nopean skaalautumisen kautta. Tämä tarkoittaa sitä, että alustaekosysteemien on oltava joustavia ja sopeuduttava jatkuvaan muutokseen. Alustahallinta edellyttää siis verkostoja dynaamisemmin muuttuvien, itseohjautuvien ekosysteemien kehitykseen vaikuttamista. Kaupunkien alustoilla on lisäksi erityinen suhde paikallisuuteen: kehitys kohti digitaalisia alustoja korostaa virtuaalisten ja fyysisten tilojen sekä globaalisuuden ja paikallisuuden vuorovaikutusta.

\section{LÄHTEET}

6Aika (2015). Tuloksia: Avoimet innovaatioalustat. Haettu sivulta https://6aika.fi/avoimet-innovaatioalustat-karkihanke-2/, 28.5.2020.

Ailisto, Heikki, Collin, Jari, Juhanko, Jari, Mäntylä, Martti, Ruutu, Sampsa, Seppälä, Timo, ... Talvitie, Jaakko (2016). Onko Suomi jäämässä alustatalouden junasta? Valtioneuvoston kanslia.

Andersson Schwarz, Jonas (2017). Platform Logic: An interdisciplinary approach to the platformbased economy. Policy \& Internet, 9(4), 374394. https://doi.org/10.1002/poi3.159

Anttiroiko, Ari-Veikko, Valkama, Pekka, Bailey, Stephen J. (2014). Smart cities in the new service economy: Building platforms for smart services. AI \& Society, 29(3), 323-334. https://doi. org/10.1007/s00146-013-0464-0

Anttiroiko, Ari-Veikko (2016). City-as-a-Platform: The rise of participatory innovation platforms in Finnish cities. Sustainability, 8(9), 922. https://doi.org/10.3390/su8090922

Anttiroiko, Ari-Veikko, Rannisto, Pasi-Heikki \& Stenvall, Jari (2018). Älykkäiden kaupunkien kehittämisalustat uutena hallinnan muotona. Teoksessa Lammintakainen, Johanna \& Laulainen, Sanna (Eds.), Kohti vaikuttavaa päätöksentekoa ja johtamista hyvinvointipalveluissa. Itä-Suomen yliopisto.

Attard, Judie, Orlandi, Fabrizio, Scerri, Simon, \& Auer, Sören (2015). A systematic review of open government data initiatives. Government Information Quarterly, 32(4), 399-418.

https://doi.org/10.1016/j.giq.2015.07.006

Auvinen, Heidi (2018). Public sector ambitions in the platform economy. Platform Value Now. Haettu sivulta https://platformvaluenow.org/ signals/public-sector-ambitions-in-the-platform-economy/, 28.5.2020.
Baldwin, Carliss \& Woodard, Jason (2009). The architecture of platforms: A unified view. Teoksessa Gawer, Annabelle (Ed.), Platforms, Markets and Innovation. Cheltenham: Edward Elgar. https://doi.org/10.4337/9781849803311

Bollier, David (2016). The City as a Platform: How Digital Networks are Changing Urban Life and Governance. The Aspen Institute.

Borghys, Koen, Van Der Graaf, Shenja, Walravens, Nils, \& Van Compernolle, Mathias (2020). Multi-stakeholder innovation in smart city discourse: Quadruple helix-thinking in the age of platforms. Frontiers in Sustainable Cities, 2. https://doi.org/10.3389/frsc.2020.00005

Bovaird, Tony, \& Loeffler, Elke (2012). From engagement to co-production: The contribution of users and communities to outcomes and public value. VOLUNTAS: International Journal of Voluntary and Nonprofit Organizations, 23(4), 1119-1138. https://doi.org/10.1007/s11266012-9309-6

Brown, Alan, Fishenden, Jerry, Thompson, Mark, \& Venters, Will (2017). Appraising the impact and role of platform models and Government as a Platform (GaaP) in UK government public service reform: Towards a platform assessment framework (PAF). Government Information Quarterly, 34(2), 167-182. https:// doi.org/10.1016/j.giq.2017.03.003

Ciborra, Claudia (1996). The platform organization: Recombining strategies, structures, and surprises. Organization Science, 7(2), 103-118. https://doi.org/10.1287/orsc.7.2.103

Cuno, Silke, Bruns, Lina, Tcholtchev, Nikolay, Lämmel, Philipp \& Schieferdecker, Ina (2019). Data governance and sovereignty in urban data spaces based on standardized ICT reference 
architectures. Data, 4(1), 16.

https://doi.org/10.3390/data4010016

Danneels, Liselot, Viaene, Stijn, \& van den Bergh, Joachim (2017). Open data platforms: Discussing alternative knowledge epistemologies. Government Information Quarterly, 34(3), 365-378.

https://doi.org/10.1016/j.giq.2017.08.007

DeNardis, Laura, \& Hackl, Andrea (2015). Internet governance by social media platforms. Telecommunications Policy, 39(9), 761-770. https://doi.org/10.1016/j.telpol.2015.04.003

Desouza, Kevin, \& Bhagwatwar, Akshay (2014). Technology-enabled participatory platforms for civic engagement: The case of U.S. cities. Journal of Urban Technology, 21(4), 25-50. https://doi.org/10.1080/10630732.2014.954898

De Waal, Martijn, de Lange, Michiel \& Bouw, Matthijs (2017). The Hackable City: Citymaking in a platform society. Architectural Design, 87(1), 50-57. https://doi.org/10.1002/ad.2131

Evans, Peter \& Gawer, Annabelle (2016). The Rise of the Platform Enterprise: A Global Survey. The Center for Global Enterprise.

Falco, Enzo \& Kleinhans, Reinout (2018). Digital participatory platforms for co-production in urban development: A systematic review. International Journal of E-Planning Research, 7(3), 52-79. https://doi.org/10.4018/IJEPR.2018070105

Gillespie, Tarleton (2010) The politics of 'platforms'. New media and society 12(3), 347-364. https://doi.org/10.1177/1461444809342738

Gorwa, Robert (2019). What is platform governance? Information, Communication \& Society, 22(6), 854-871. https://doi.org/10.1080/13691 18x.2019.1573914

Hagiu, Andrei, \& Yoffie, David (2009). What's your Google strategy? Harvard Business Review, 87(4), 74-81.

Hajian, Sara, Bonchi, Francesco, \& Castillo, Carlos (2016). Algorithmic bias: From discrimination discovery to fairness-aware data $\mathrm{min}$ ing. Proceedings of the 22nd ACM SIGKDD International Conference on Knowledge Discovery and Data Mining, 2125-2126. https://doi.org/10.1145/2939672.2945386

Hein, Andreas, Schreieck, Maximilian, Riasanow, Tobias, Setzke, David, Wiesche, Manuel, Böhm, Markus, \& Krcmar, Helmut (2020). Digital platform ecosystems. Electronic Markets, 30(1), 87-98. https://doi.org/10.1007/s12525-019-00377-4

Helsinki Region Infoshare (2017). HRI-palvelu. Haettu sivulta https://hri.fi/fi/hri-palvelu/, 28.12.2020.
Hendriks, Frank (2014). Understanding good urban governance: Essentials, shifts and values. Urban Affairs Review, 2014, 50(4) 553-576. https://doi.org/10.1177/1078087413511782

Janowski, Tomasz, Estevez, Elsa, \& Baguma, Rehema (2018). Platform governance for sustainable development: Reshaping citizen-administration relationships in the digital age. Government Information Quarterly, 35(4), S1S16. https://doi.org/10.1016/j.giq.2018.09.002

Janssen, Marijn \& Estevez, Elsa (2013). Lean government and platform-based - Doing more with less. Government Information Quarterly, 30(1), S1-S8.

https://doi.org/10.1016/j.giq.2012.11.003

Jin, Dal Yong (2015). Digital Platforms, Imperialism and Political Culture. Routledge. https://doi.org/10.4324/9781315717128

Kenney, Martin \& Zysman, John (2016). The rise of the platform economy. Issues in Science and Technology 32(3), 61-69.

Kronsell, Annica \& Mukhtar-Landgren, Dalia (2018). Experimental governance: The role of municipalities in urban living labs. European Planning Studies, 26(5), 988-1007.

https://doi.org/10.1080/09654313.2018.1435631

Larsson, Stefan, \& Andersson Schwarz, Jonas (2018). A platform society. Teoksessa Larsson, Stefan, \& Andersson Schwarz, Jonas (Eds.), Developing Platform Economies: A European Policy Landscape. (s. 114-140). Brussels \& Stockholm: European Liberal Forum asbl.

Lee, Gwanhoo \& Kwak, Young Hoon (2012). An open government maturity model for social media-based public engagement. Government Information Quarterly, 29(4), 492-503. https://doi.org/10.1016/j.giq.2012.06.001

Lember, Veiko, Brandsen, Taco \& Tõnurist, Piret (2019). The potential impacts of digital technologies on co-production and co-creation. Public Management Review, 21(11), 1665-1686. https://doi.org/10.1080/14719037.2019.1619807

Liu, Helen (2017). Exploring online engagement in public policy consultation: The crowd or the few? Australian Journal of Public Administration, 76(1), 33-47. https://doi.org/10.1111/1467-8500.12209

Love, Jim (2015). Smart Cities Push Public Engagement over Public Policy: IBM Strategist. IT World Canada. Haettu sivulta http://www.itworldcanada.com/article/what-can-it-leaderslearnfrom-smart-cities-a-lot/377281, 28.5.2020.

Lulin, Elisabeth (2017). Smart cities and sharing cities: How to foster collaborative local public services. Field Actions Science Reports, Special Issue 16, 66-69. 
Millard, Jeremy. (2018). Open governance systems: Doing more with more. Government Information Quarterly, 35(4), S77-S87. https:// doi.org/10.1016/j.giq.2015.08.003

Nash, Victoria, Bright, Jonathan, Margetts, Helen, \& Lehdonvirta, Vili (2017). Public policy in the platform society. Policy \& Internet, 9(4), 368373. https://doi.org/10.1002/poi3.165

Nooren, Pieter, van Gorp, Nicolai, van Eijk, Nico, Fathaig, Ronan (2018). Should we regulate digital platforms? A new framework for evaluating policy options. Policy \& Internet 10(3), 264-301. https://doi.org/10.1002/poi3.177

Offenhuber, Dietmar, Yamagata, Yoshiki, \& Yang, Perry (2019). The platform and the bricoleurimprovisation and smart city initiatives in Indonesia. Environment and Planning B: Urban Analytics and City Science, 46(8), 1565-1580. https://doi.org/10.1177/2399808319865749

O'Reilly, Tim (2011). Government as a Platform. Innovations: Technology, Governance, Globalization, 6(1), 13-40.

https://doi.org/10.1016/j.giq.2017.03.003

Osborne, Stephen (2010). The New Public Governance? Emerging Perspectives on the Theory and Practice of Public Governance. London; Routledge. https://doi.org/10.4324/9780203861684

Pasquale, Frank (2016). Platform neutrality: Enhancing freedom of expression in spheres of private power. Theoretical Inquiries in Law, 17(2) 487-513. https://doi.org/10.1515/til-2016-0018

Pierre, Jon \& Peters, Guy (2000). Governance, Politics and The State. London: Macmillan

Plantin, Jean-Christophe (2019). Review essay: How platforms shape public values and public discourse. Media, Culture \& Society, 41(2), 252-257. https://doi.org/10.1177/0163443718818378

Ranerup, Agneta, Henriksen, Helle, Hedman, Jonas (2016). An analysis of business models in public service platforms. Government Information Quarterly, 33(1), 6-14. https://doi.org/10.1016/j.giq.2016.01.010

Raymond, Eric (1999). The cathedral and the bazaar. Knowledge, Technology \& Policy, 12(3), 23-
49. https://doi.org/10.1007/s12130-999-1026-0

Rhodes, Roderick A. W. (1996). The new governance: Governing without government. Political Studies, 44(4), 652-667.

https://doi.org/10.1111/j.1467-9248.1996. tb01747.x

Seppälä, Timo, Halén, Marco, Juhanko, Jari, Korhonen, Heidi, Mattila, Juri, Parviainen, ... \& Ruutu, Sampsa (2015). "Platform" - Historiaa, ominaispiirteitä ja määritelmä. ETLA.

Siivouspäivä (2020). Siivouspäivä kunnille. Haettu sivulta https://siivouspaiva.com/kunnille, 22.12.2020.

Sotarauta, Markku, Hyrskyluoto, Jorma, Rosenlund, Mikko \& Vilpponen, Jani (2018). Alustatalouden haaste ja pankkien tulevaisuus. Teoksessa Mähönen Jukka, Pölönen Pasi \& Vahtera, Veikko (Eds.), Juhlajulkaisu Risto Nuolimaa 1948 - 2/6 - 2018. (s. 305-318). Suomalainen Lakimiesyhdistys.

Sotarauta, Markku \& Suvinen, Nina (2019). Place leadership and the challenge of transformation: Policy platforms and innovation ecosystems in promotion of green growth. European Planning Studies, 27(9) 1748-1767. https://doi.org/10.10 80/09654313.2019.1634006

Stoker, Gerry (2011). Was local governance such a good idea? A Global comparative perspective. Public administration, 89(1), 15-31. https://doi. org/10.1111/j.1467-9299.2011.01900.x

Thomas, Llewellyn, Autio, Erkko, Gann, David (2014). Architectural leverage: putting platforms in context. The Academy of Management Perspectives, 28(2), 198-219. https://doi.org/10.5465/amp.2011.0105

Tiwana, Amrit (2014). Platform Ecosystems: Aligning Architecture, Governance, and Strategy. MK.

Van Dijck, José, Poell, Thomas \& de Waal, Martijn (2018). The Platform Society: Public Values in A Connective World. New York, NY: Oxford University Press.

Williamson, Oliver E. (1975). Markets and Hierarchies: Analysis and Antitrust Implications. New York: Free Press. 